\title{
Benign Intracerebellar Cyst without Epithelial Lining
}

\author{
SHUNSUKE SUGITA, YASUO SUGITA, EIICHIRO HONDA, AKIRA OKURA, \\ KAZUYA MORIMOTO, HITOSHI MORIMITSU, NAOKO FUJIMURA, \\ TERUKAZU KURAMOTO AND MINORU SHIGEMORI \\ Department of Neurosurgery, Kurume University School of Medicine, \\ Kurume, 830 Japan
}

Received for publication August 22, 1994

\begin{abstract}
Summary: A case of benign intracerebellar cyst is reported in a 61-yearold woman who presented progressive neurological deficits. MRI and operative findings could not reveal any evidence of neoplastic growth. The biopsied cyst wall revealed normal cerebellar tissue. The simple cyst of the cerebellum is rare, thus we discuss the clinical features and ethiology of this rare entity.
\end{abstract}

Key words: benign cyst - non-neoplastic cyst - intracerebellum - CT MRI

\section{Introduction}

Many types of benign intracerebellar cysts have been described. However, solitary non-neoplastic intracerebellar cysts that have walls without epithelial lining are very rare (Antoni, 1926; Lindau, 1926; Szigethy, 1928; Cushing, 1931; Silverberg, 1971; Sundbarg et al. 1972; Vaquero et al. 1981; Weisberg , 1982). Though these cysts cause progressive neurological deficits, CT or MRI fail to detect any enhanced lesions. These cysts are usually filled with clear or yellow fluid and biopsies of the cysts wall reveal only neuroglial tissues without ependyma or arachinoid.

\section{Case Report}

A 61-year-old woman came to our hos- pital with a 2-month history of headache, ataxic gait and dizziness. A marked progression of her symptoms was observed during the month before admission. Her consciousness was clear and her neurological examination showed broad-based ataxic gait, truncal ataxia and impairment of tandem walk. Bilateral papilledema was also seen. The reflexes were normal. Hemoglobin, white blood cell count, urinalysis, electrolytes and liver function were normal. CT scan revealed a non-enhancing hypodensity mass in the cerebellar vermis. MRI showed hypointensity and hyperintensity mass lesion on the T1-weighted image and the T2weighted image, respectively. A detailed MRI examination could not detect any mural nodule or tumoral lesion. The fourth ventricle was compressed by the vermian mass, but had no communi-

Address for correspondence: Dr. S. Sugita, Department of Neurosurgery, Kurume University School of Medicine, 67 Asahi-machi, Kurume, 830 Japan. 
cation. A tonsillar herniation was observed (Fig. 1). Vertebral angiography showed an avascular mass with stretching of the posterior inferior cerebellar arteries. A suboccipital craniectomy with laminectomy of the C-1 vertebra exposed a large cyst of the vermis, filled with clear fluid. Operative exposure showed no mural nodule and no communication with the fourth ventricle. Several biopsies, taken from the cyst wall, showed normal cerebellar tissue, no evidence of hemorrhage or neoplasm (Fig. 2). Her postoperative course was excellent. During the following days, her neurological deficits improved gradually. Three years after surgery, her neurological examination showed no abnormality.

\section{Discussion}

A non-neoplasmic cyst can arise from a degenerated area of the brain, as a sequel to processes such as infection, parasitosis, hemorrhage, infarction or trauma. However, in our case, we could not find any evidence of lesions through neuroradiological, operative and histological examinations. Furthermore, a non-neoplastic intraparenchymal brain cyst can be congenital; most case reported were arachnoid cyst and porencephaly (Harsh et al. 1986); others were epithelial cyst, ependymal cyst and colloidal cyst (Schenk, 1966; Jakubiak et al. 1968; Bouch et al. 1973; Palma, 1975; MacGregor et al. 1976; Friede and Yasargil, 1977; Azzam and Timperley, 1981; Giombini et al. 1981; Markwalder et al. 1981; Takeshita et al. 1982; Oro et al. 1983; Inoue et al. 1985). However, the histopathological findings showed that
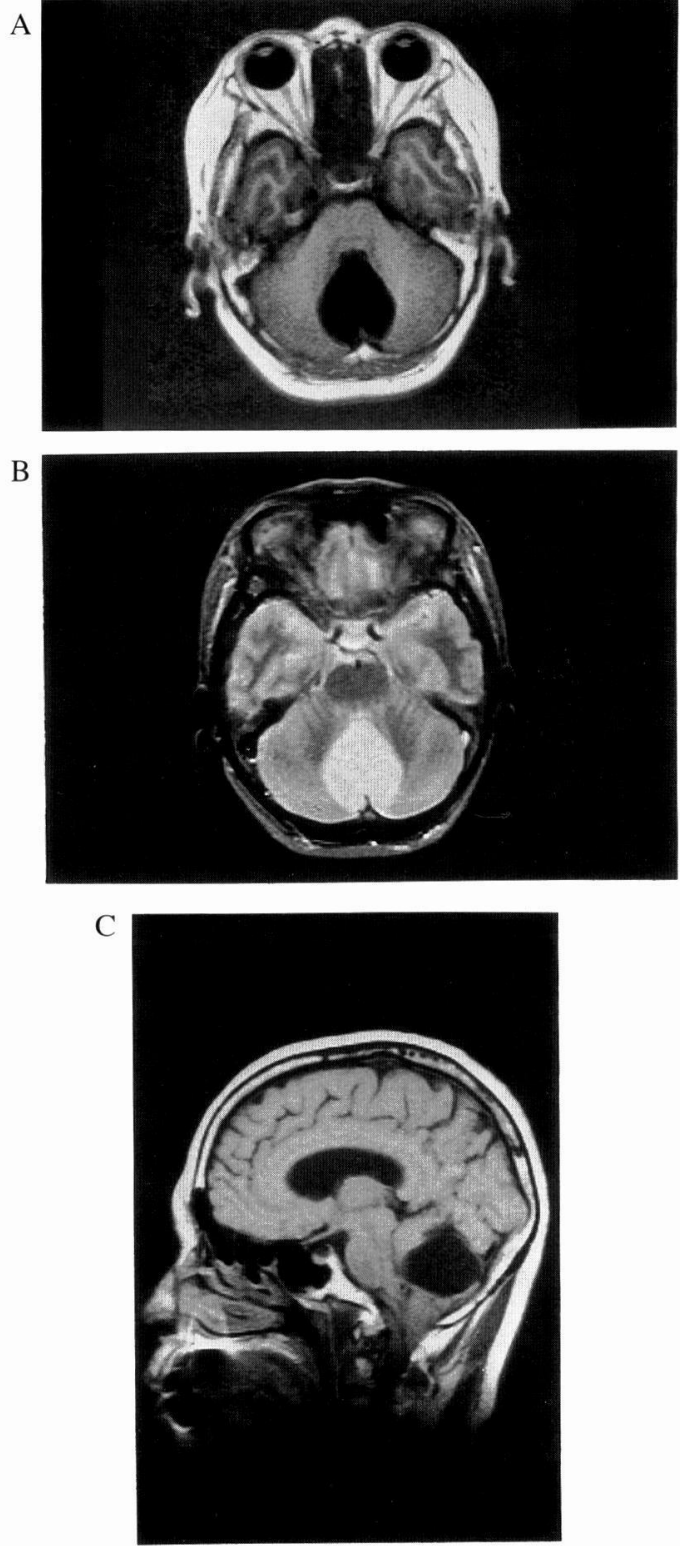

Fig. 1. MRI shows hypointensity and hyperintensity mass lesion in the cerebellar vermis on the T1-weighted image (A) and T2-weighted image (B), respectively. The fourth ventricle is compressed by the vermian mass. Sagittal imaging also reveals the vermian mass lesion (C). Tonsillar herniation can be observed. 


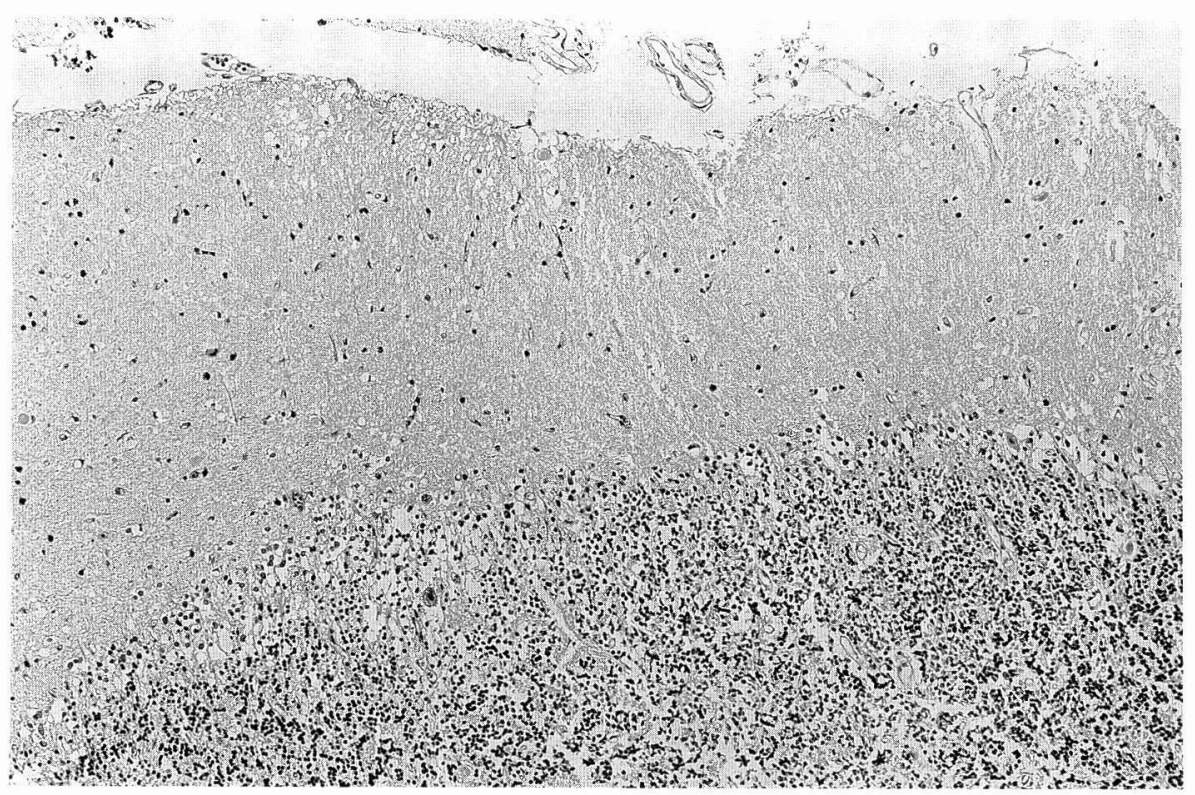

Fig. 2. Photomicrograph of a histological section showing that the wall of the cyst consists of normal cerebellar tissue. There is no epithelial lining. $\mathrm{H} \& \mathrm{E}, \times 100$.

our case was different from all these reported cases. To our knowledge, there were fifteen cases of cerebellar cysts reported, including our case, where histological examination of the cyst wall showed normal cerebellar tissue with glial reaction (Table 1) (Antoni, 1926; Lindau, 1926; Szigethy, 1928; Cushing, 1931; Silverberg, 1971; Sundbarg et al. 1972; Vaquero et al. 1981; Weisberg, 1982). The etiology and pathogenesis of these cysts are not clear. Silverberg (1971) considered that these cysts do not have a congenital origin but rather represent a degeneration of a cerebellar astrocytoma which could contain xanthocromic fluid. The fact that 8 out of 15 reported cases of simple cerebellar cysts contained a yellow or protein-rich fluid is consistent with this view. Vaquero et al. (1981) also supported this hypothesis because radiograms of their case, a 25- year-old man, revealed the signs of chronic intracranial hypertension and marked thinning of the bone in the occipital area. Three cases of similar supratentorial cysts were reported in one decade (Nakasu et al. 1986; Wilkins and Burger, 1988; Wester and Pedersen, 1992). Pathohistological studies of these cyst walls also showed normal brain tissues without epithelial lining and connection of the ventricle. Wilkins et al. (1988) considered that such cysts might be formed by budding from the ventricular system, with subsequent loss of ependymal cells. In our case, the cyst arised from near the fourth ventricle and was full of clear fluid. Furthermore, detailed neuroradiological studies and operative exploration failed to prove any evidence of a mural tumor nodule. Therefore, we speculate that our case of cyst in the cerebellum may have orig- 
TABLE 1.

Fifteen cases of cerebellar cyst without epithelial lining

\begin{tabular}{|c|c|c|c|c|c|c|}
\hline $\begin{array}{l}\text { Case } \\
\text { No. }\end{array}$ & Author(s) & $\begin{array}{l}\text { Age/ } \\
\text { Sex }\end{array}$ & Symptoms & Location & $\begin{array}{l}\text { Fluid within } \\
\text { the cyst }\end{array}$ & $\begin{array}{l}\text { Histopathological findings } \\
\text { of the cyst wall }\end{array}$ \\
\hline 1 & $\begin{array}{l}\text { Antoni } \\
(1926)\end{array}$ & $45 \mathrm{~F}$ & $\begin{array}{l}\text { headache, vomiting, ataxic } \\
\text { gait }\end{array}$ & $\begin{array}{l}\text { right cerebellar } \\
\text { hemisphere }\end{array}$ & $?$ & $\begin{array}{l}\text { cell-poor neuroglial fibers, many } \\
\text { Rosenthal fibers, no tumor }\end{array}$ \\
\hline 2 & $\begin{array}{r}\text { Lindau } \\
(1926)\end{array}$ & $52 \mathrm{M}$ & $\begin{array}{l}\text { headache, vomiting, } \\
\text { dizziness, died prior to surgery }\end{array}$ & $\begin{array}{l}\text { cerebellar } \\
\text { vermis }\end{array}$ & $\begin{array}{l}\text { protein-rich } \\
\text { yellow fluid }\end{array}$ & thick glial fibers, no tumor \\
\hline 3 & $\begin{array}{l}\text { Szigethy } \\
\text { (1928) }\end{array}$ & $47 \mathrm{~F}$ & $\begin{array}{l}\text { vomiting, dizziness, } \\
\text { papilledema, left-sided } \\
\text { dysmetria, died in } 1 \text { week }\end{array}$ & $\begin{array}{l}\text { left cerebellar } \\
\text { hemisphere } \\
\text { including vermis }\end{array}$ & yellow fluid & glial fibers, no tumor \\
\hline 4 & $\begin{array}{l}\text { Cushing } \\
\text { (1931) }\end{array}$ & $? \mathrm{M}$ & $\begin{array}{l}\text { acromegaly, mild cerebellar } \\
\text { symptoms }\end{array}$ & cerebellum & $\begin{array}{l}\text { xanthocromic } \\
\text { fluid }\end{array}$ & non-neoplastic portion \\
\hline 5 & $\begin{array}{l}\text { Silverberg } \\
\text { (1971) }\end{array}$ & $50 \mathrm{M}$ & $\begin{array}{l}\text { headache, vomiting, } \\
\text { nystagmus, Romberg sign } \\
\text { positive, ataxia }\end{array}$ & $\begin{array}{l}\text { right cerebellar } \\
\text { hemisphere }\end{array}$ & $\begin{array}{l}\text { protein-rich } \\
\text { yellow fluid }\end{array}$ & $\begin{array}{l}\text { multiple interlacing glial fibers } \\
\text { adjacent to the granular cell layer, no } \\
\text { tumor or hemorrhage }\end{array}$ \\
\hline 6 & $\begin{array}{l}\text { Silverberg } \\
\text { (1971) }\end{array}$ & $62 \mathrm{M}$ & disorientation, truncal ataxia & $\begin{array}{l}\text { cerebellar } \\
\text { vermis }\end{array}$ & $\begin{array}{l}\text { protein-rich } \\
\text { yellow fluid }\end{array}$ & $\begin{array}{l}\text { variety of sizes and shapes of the } \\
\text { hyaline Rosenthal fibers, no evidence } \\
\text { of tumor }\end{array}$ \\
\hline 7 & $\begin{array}{l}\text { Silverberg } \\
\text { (1971) }\end{array}$ & $52 \mathrm{~F}$ & $\begin{array}{l}\text { headache, vomiting, } \\
\text { papilledema, nystagmus, } \\
\text { unsteadiness of gait }\end{array}$ & $\begin{array}{l}\text { left cerebellar } \\
\text { hemisphere }\end{array}$ & yellow fluid & $\begin{array}{l}\text { several large astrocytes and stellate } \\
\text { cell bodies within a loose, cystic, glial } \\
\text { fiber meshwork }\end{array}$ \\
\hline 8 & $\begin{array}{l}\text { Silverberg } \\
\text { (1971) }\end{array}$ & $70 \mathrm{M}$ & $\begin{array}{l}\text { dysphonia, palsies of CN 9-12, } \\
\text { neurofibroma arose from CN9, } \\
\text { headache, vomiting, ataxia, } \\
\text { died } 1 \text { month after radiation }\end{array}$ & $\begin{array}{l}\text { left cerebellar } \\
\text { hemisphere }\end{array}$ & $?$ & similar to case 5 , no tumor \\
\hline 9 & $\begin{array}{l}\text { Sundbarg et al. } \\
\text { (1972) }\end{array}$ & $62 \mathrm{~F}$ & papilledema & $\begin{array}{l}\text { cerebellar } \\
\text { vermis }\end{array}$ & yellow fluid & $\begin{array}{l}\text { located in both the white and gray } \\
\text { matter, extensive spongy vacuolization } \\
\text { change and mild gliosis }\end{array}$ \\
\hline 10 & $\begin{array}{l}\text { Vaquero et al. } \\
\text { (1981) }\end{array}$ & $25 \mathrm{~F}$ & $\begin{array}{l}\text { headache, vomiting, diplopia, } \\
\text { papilledema, truncal ataxia, } \\
\text { dysmetria on the left }\end{array}$ & $\begin{array}{l}\text { left cerebellar } \\
\text { hemisphere }\end{array}$ & $?$ & $\begin{array}{l}\text { cerebellar tissue with edema and } \\
\text { gliosis }\end{array}$ \\
\hline 11 & $\begin{array}{l}\text { Vaquero et al. } \\
\text { (1981) }\end{array}$ & $46 \mathrm{M}$ & $\begin{array}{l}\text { headache, vomiting, dizziness, } \\
\text { papilledema, truncal ataxia }\end{array}$ & $\begin{array}{l}\text { right cerebellar } \\
\text { hemisphere }\end{array}$ & $\begin{array}{l}\text { non-xanthocro- } \\
\text { mic fluid }\end{array}$ & cerebellar tissue with gliosis \\
\hline 12 & $\begin{array}{l}\text { Weisberg } \\
(1982)\end{array}$ & $55 \mathrm{~F}$ & $\begin{array}{l}\text { headache, vomiting, ataxic } \\
\text { gait, truncal ataxia, } \\
\text { nystagmus, papilledema }\end{array}$ & $\begin{array}{l}\text { cerebellar } \\
\text { hemisphere }\end{array}$ & yellow fluid & $\begin{array}{l}\text { gray-white gliotic cyst wall, no } \\
\text { evidence of hemorrhage }\end{array}$ \\
\hline 13 & $\begin{array}{l}\text { Weisberg } \\
(1982)\end{array}$ & $50 \mathrm{M}$ & $\begin{array}{l}\text { progressive gait instability, } \\
\text { headache, vomiting }\end{array}$ & $\begin{array}{l}\text { unilocular vermis } \\
\text { and right cerebellar } \\
\text { hemisphere }\end{array}$ & clear fluid & $\begin{array}{l}\text { gliotic cell wall with prominent } \\
\text { vascular change and no evidence of } \\
\text { hemorrhage }\end{array}$ \\
\hline 14 & $\begin{array}{l}\text { Weisberg } \\
(1982)\end{array}$ & $25 \mathrm{~F}$ & $\begin{array}{l}\text { gait and truncal ataxia, right } \\
\text { CN6 paresis }\end{array}$ & $\begin{array}{l}\text { multilocular ver- } \\
\text { mian and medial left } \\
\text { cerebellar cyst }\end{array}$ & clear fluid & $\begin{array}{l}\text { grayish-white and tan tissue with no } \\
\text { evidence of neoplash normal } \\
\text { cerebellar tissue with gliotic reaction }\end{array}$ \\
\hline 15 & Present case & $61 \mathrm{~F}$ & $\begin{array}{l}\text { gait and truncal ataxia, } \\
\text { headache, dizziness, } \\
\text { papilledema }\end{array}$ & $\begin{array}{l}\text { cerebellar } \\
\text { hemisphere }\end{array}$ & clear fluid & $\begin{array}{l}\text { normal cerebellar tissue, no tumor and } \\
\text { hemorrhage }\end{array}$ \\
\hline
\end{tabular}


inated from this mechanism. More detailed examinations of future cases might give an answer to what the nature of a benign cerebellar cysts is.

Non-neoplastic cerebellar cysts are encountered in late-to-middle aged patients (see Table 1) (Weisberg, 1982). So the next question is how a cyst can expand and grow slowly. The cyst usually contains protein-rich fluid, and exists near the ventricle system. CSF might permeate a cyst due to an osmotic difference.

Surgical treatment, which consisted of opening or aspirating the cysts, brought about good results. Thus, an accurate diagnosis and operation are very important for a patient who is suffering from benign cerebellar cyst.

\section{References}

Antoni, N. (1926). Kystes cerebelleux, la syringomyelie du cervelet. Acta Otolaryngol. 9, 1-42.

Azzam, N.I. and Timperley, W.R. (1981). Intracerebral cyst due to ectopic chroid plexus. Case report. J. Neurosurg. 55, 651-653.

Bouch, D.C., Mitchell, I. and Maloney, A.F.J. (1973). Ependymal lined paraventricular cerebral cysts; a report of three cases. J. Neurol. Neurosurg. Psychiatry 36, 611-617.

Cushing, H. (1931). Experiences with the cerebellar astrocytomas: a critical review of seventy-six cases. Surg. Gyn. Obstet. 52, 129-204.

Friede, R.L. and YASARGIL, M.G. (1977). Supratentorial intracerebral epithelial (ependymal) cysts: review, case reports, and fine structure. J. Neurol. Neurosurg. Psychiatry 40, 127-137.

Grombin, S., Sandro, L. and Migiavacca, F. (1981). Intracranial enterogenous cyst. Surg. Neurol. 16, 271-273.
Harsh, G.R.I.V., EDwards, M.S.B and Wilson, C.B. (1986). Intracranial arachnoid cysts in children. J. Neurosurg. 64, 835-842.

Inoue, T., Kuromatsu, C., Iwata, Y. and Matsushima, T. (1985). Symptomatic chroidal epithelial cyst in the fourth ventricle. Surg. Neurol. 24, 57-62.

Jakubiak, P., Dunsmore, R. H. and Beckett, R.S. (1968). Supratentorial brain cysts. J. Neurosurg. 28, 129-136.

Lindau, A. (1926). Studien über Kleinhirnzysten Bau, Pathogenese und Beziehungen zur Angiomatosis retinae. Acta Pathol. Microbiol. Scand. 2 Supple 1.

MacGregor, B.J.L., Gawler, P.J. and South, J.R. (1976). Intracranial epithelial cysts. Report of two cases. J. Neurosurg. 44, 109-115.

Markwalder, T-M., Markwalder, R.V. and Slongol, T. (1981). Intracranial neuroepithelial cyst mimicking arachnoid cyst. Surg. Neurol. 16, 411-414.

Markwalder, T-M and Zimmerman, A. (1979). Intracerebral epithelial cyst. Surg. Neurol. 11, 195-198.

Nakasu, Y., Handa, J. and Watanabe, K. (1986). Progressive neurological deficits with benign intracerebral cysts. Report of two cases. J. Neurosurg. 65, 706-709.

Oro, J.J., ANSBScher, L.E. and LevY, W.J. (1983). Septate bifrontal ependymal cyst. Case report. J. Neurosurg. 59, 344-347.

PALMA, L. (1975). Supratentorial neuroepithelial cysts. Report of two cases. J. Neurosurg. 42, 353-357.

Schenk, V.W.D. (1966). Congenital cavities of the posterior fossa. Acta Neuropathologica 6, 117-126.

SHimisu, T. and WAGA, S. (1984). Intraventricular noncolloid epithelial cyst in an infant. Surg. Neurol. 21, 185-189.

Silverberg, G.D. (1971). Simple cysts of the cerebellum. J. Neurosurg. 35, 320-327.

Solt, L.C., Deck, J.H.N., Baim, R.S. and Terbrugge, K. (1980). Interhemispheric cyst of neuroepithelial origin in association with partial agenesis of the corpus callosum. Case 
report and review of the literature. J. Neurosurg. 52, 399-403.

Sundbarg, G., Brun, A. and Efsing, H.O. (1972).

Non-neoplastic expanding lesions of the vermis cerebelli. J. Neurosurg. 37, 55-74.

Szigethy, A.V. (1928). Beiträge zur Genese der Kleinhirnzystem. Arch Psychiatry 84, 715725.

Takeshita, M., Miyazaki, T., Kubo, O., Kagawa, M., SaIto, Y. et al. (1982). Paraventricular cerebral cyst in an infant. Surg. Neurol. 17, 123-126.

VAquero, J., Cabezudo, J.M. and Areitio, E.
(1981). Glial cysts of the cerebellum. Surg. Neurol. 16, 288-289.

WeisBerg, L.A. (1982). Non-neoplastic gliotic cerebellar cyst: clinical and computed tomographic correlations. Neuroradiology 24, 53-57.

Wester, K. and Pedersen, P-H. (1992). Benign intracerebral cysts treated with internal shunts: Review and report of two patients. Neurosurgery 30, 432-436.

WiLkins, R.H. and Burger, P.C. (1988). Benign intraparenchymal brain cysts without an epithelial lining. J. Neurosurg. 68, 378-382. 